\title{
Adaptation à différents milieux des systèmes de production des paysans du Haut-Atlas
}

Alain Bourbouze

\section{(2) OpenEdition}

Édition électronique

URL : https://journals.openedition.org/tc/904

DOI : $10.4000 /$ tc. 904

ISSN : 1952-420X

Éditeur

Éditions de l'EHESS

\section{Édition imprimée}

Date de publication : 1 septembre 1986

ISSN : 0248-6016

\section{Référence électronique}

Alain Bourbouze, «Adaptation à différents milieux des systèmes de production des paysans du HautAtlas », Techniques \& Culture [En ligne], 7| 1986, mis en ligne le 23 janvier 2006, consulté le 29

septembre 2022. URL : http://journals.openedition.org/tc/904 ; DOl : https://doi.org/10.4000/tc.904

Ce document a été généré automatiquement le 29 septembre 2022.

Tous droits réservés 


\section{Adaptation à différents milieux des systèmes de production des paysans du Haut-Atlas}

Alain Bourbouze 